\title{
Impact of Project-Based Learning on Entrepreneurial and Social Skills Development
}

\author{
Avila Priya Pinto ${ }^{1}$, Reshma KJ ${ }^{2}$ \\ ${ }^{1}$ ECE Department, St Joseph Engineering College, Vamanjoor, Mangaluru, Karnataka India \\ ${ }^{2}$ ECE Department, St Joseph Engineering College, Vamanjoor, Mangaluru, Karnataka India \\ 1appinto1985@gmail.com \\ reshmak@sjec.ac.in
}

\begin{abstract}
The management and entrepreneurship subject in the engineering curriculum is the most imperative at the same time overlooked subject when it comes to experiential learning. Therefore, it was realized that there is a need to bring up some innovations concerning course content delivery strategies and assessment to improve the entrepreneurial and social skills among the students. The purpose of this study is to find the impacts of projectbased learning and identify all factors that influence our students to get succeed. This exposed students to numerous opportunities to learn how to think critically and analyze the ideas on board. The flip classroom is used to describe the concept, and Project-Based Learning served as a tool for the students to develop their Entrepreneurial Skills. These strategies helped the students to continue learning on the topic further. They discovered various job opportunities, career paths they thought of or known existed. This type of instructional method repurposed the class hours for an inquiry which was beneficial for students to learn better. The pedagogical practices which are discussed here were found to be the most effective ones when compared with conventional classroom teaching and in terms of student's involvement in learning. It is perceived that to unleash our students' entrepreneurial skills, curricula must include outcomes that enable lifelong learning and encourage inquiry beyond the classroom rather than only defining measurable learning outcomes. The current research motivated the students to submit business plans for startups.
\end{abstract}

Keywords: project-based learning, social and entrepreneurial skills

\section{Introduction}

Management and Entrepreneurial Development subject in Engineering curriculum focuses on developing skills of students to face the competitive world. Students with sound knowledge of technology but lacking in exhibiting social skills may not render the society with corporate social responsibilities as well as they may not see their personal growth more convincingly. Entrepreneurship education needs interactive learning through business and community initiatives [1]. This suggests having an interactive connection between the industry and entrepreneurship education due to its experience type learning method. There is a need to develop social skills in dealing with superiors and clients. New pedagogies are trending now, and different teaching practices are being implemented.

Project-Based Learning is a unique learning method that enables students to gain more knowledge and acquire new skills beyond classroom teaching. It generates creative methods that help students transform their ideas into a product, service, or process. It teaches students to think creatively and achieve high-performance objectives to facilitate individual and collaborative learning [5]. Students can adapt their learning through inquiry, and also have collaborative research plans to create projects that enhance their learning skills. Students become proficient communicators and advanced problem solvers, using this method. Project-based learning is the best method to engage students to evaluate a problem more critically for deeper understanding.

The implementation of the PBL method will significantly supplement the social skills of the student. The main objective of this method is to improve the overall competency and skills of the students. It also helps students to improve their confidence.

Through this research, the attempt is made to improve the social skills of the student to understand the concept of social responsibilities of business \& the challenges in entrepreneurship. In the PBL method, students are better engaged through real-world activities with well-timed feedback, and eventually, that will lead to better outcomes.

Researchers were motivated to establish the following Research Questions (RQs) concerning the topic of interest.

RQ1:What are the challenges associated with defining the concepts of Entrepreneur and Entrepreneurship?

RQ2: What are the types of assistance needed by the respondents to promote entrepreneurship?

RQ3: What are the strategies for the effective implementation of project Based learning on Entrepreneurial and social skills development?

\section{Literature Review}


To begin with any entrepreneurial activity, there is a critical need for prior exposure to it. Various situations and critical incidents during the entrepreneurial experience the higher level of learning happens. This higher level of learning includes mentoring support during difficult times, personal experience, the lesson from the failure, etc. These incidents support the learner to contemplate and consider them as a learning experience [1]. Many researchers contend that to master the entrepreneurship process, individuals need to possess some prior engagement in similar entrepreneurial activity and gain experience. Education plays a significant role in introducing any new skill to the learners. It is empirical from the earlier researches that Entrepreneurship education driven by experience is more impactful than any other systematic teaching approach [2].To explore the various opportunities and challenges involved in business and to get the experience of the various facets, the learner's involvement must be beyond classroom boundaries. More interaction ensures new experience, and this in turn assures the learning [3]. The "Learning-bydoing" element in every pedagogy of teaching and learning will stimulate the design of outside-theclassroom activities. In entrepreneurship education programs, exposing the students to successful entrepreneurial models could be an excellent factor for reviving their confidence in starting a business as well as their attitudes towards entrepreneurship [7].

It is very much needed to employ suitable teaching and learning techniques in today's world, considering the millennial learner's capabilities and shortcomings. In this direction, the entrepreneurship education curriculum itself has to provide a framework and promote the pedagogical teaching methods to enhance student engagement. The researchers have prescribed quite a few methodologies to improve effective learning in management and entrepreneurship [8]. The nature and ability of entrepreneurship education have been transforming over the years. With more exposure to the economic conditions and with fast-growing digital technologies, entrepreneurs can develop innovative entrepreneurial actions that progress beyond the traditional way of doing business and accelerate the entrepreneurial activity [9]. The students who are taught by multiple intelligences supported with project-based learning methods are more fortunate because of their higher motivation level than the students who are educated by the conventional instructional methods[12]. Entrepreneurship focuses on building realworld skills that will assist the students to lead extraordinary lives in this competitive as well as ambitious world. The students have to develop their management skills, accept and build their competitive side, and learn to take more risks. Although the traditional form of education has been with us for some years, experiential education is a contemporary form of education that has appeared in recent years. It analyses the learning styles of the individual learners and designs the teaching material accordingly so that every student can appreciate the learning by expanding their abilities, such as memory, creativity, and sensitivity to achieve knowledge [15]. In this way, discoveries and experiments help the students to gain interest in converting their business plans into start-ups. The factual and verifiable shreds of evidence show that experiential education addresses particular methods, and Project-Based Learning is one of them. "The fundamental idea of Project Based Learning is that, making the students inquisitive towards real-world problems and capture their interest and arouse serious thinking as the students obtain and apply new thinking in a problem-solving context. The teacher is characterized by a facilitator here, working with students from the design of the activity such as framing worthwhile questions, structuring meaningful tasks, to coaching them in the execution of the task. In this process student's both knowledge and social skills development will take place. Finally assessing the students' performance in executing the activity will be done by the facilitator [14].

\section{Methodology}

Based on the objectives, a study was developed, organized, and conducted. Two different activities were conducted wherein the survey of entrepreneurs as well as interaction with entrepreneurs was conducted. The first activity was conducted in teams. The participants included 120 students of Third year ECE Engineering. Teams consisting of 5 students each with different learning styles were grouped and instructed to meet Entrepreneurs in the city and document their success/failure stories including their CSR activities.

The concepts of corporate social responsibility were explained using the flipped classroom method. A flipped classroom requires strong motivation from students. In this method the instructor had mailed students a prerecorded video on CSR, to enable them to understand the concepts. They were required to present the concepts in the classroom one week later in the form of a presentation or discussion among their classmates. Flipped learning method enhanced student learning experience outside the classroom. This flipped classroom methodology provided them with a clear structure for understanding and learning concepts in their own time.

The next approach implemented was project-based learning for understanding Entrepreneurship techniques. All these activities, initiatives, visits, and talks are aimed at sparking new ideas and motivation in students' minds.

The second activity was carried out using the survey. Entrepreneurs were interviewed with a set of a good questionnaire consisting of close-ended questions using the Likert scale method. This method is an essential research tool to gauge the attitudes, opinions of respondents when responding to specific questions.

The survey helped to analyze youth perception towards entrepreneurship. The questionnaires given to respondents were divided into four diagnostic sections.

i.About respondent;

ii.About entrepreneurship and enterprise establishment 
iii. About attitude towards an entrepreneur and what features he/she need to possess

iv.About travel requires a lot of physical and mental endurance.

Eighty Five respondents participated in the survey. The information gathered from the survey reflected on the prior knowledge possessed by the entrepreneurs regarding entrepreneurship, the amount of risk involved, the success attained after taking the risk, the failure seen after taking the risk, the optimism required while running the business. The respondents included the combination of men and women Entrepreneurs, who were opted by the students themselves. The summary is listed here:

a) $90 \%$ of respondents feel they lack entrepreneurship knowledge/skills for becoming entrepreneurs.

b) $40 \%$ of the respondents mentioned that they had taken the risk of becoming entrepreneurs and they succeeded.

c) $35 \%$ of the respondent mentioned that they had taken the risk of becoming entrepreneurs and they failed.

d) $25 \%$ of the respondent mentioned that they had taken it as a challenge of becoming entrepreneurs and they are on the way to success.

e) $60 \%$ of the respondents indicated that they would not mind trying for new projects, even if they require physical and mental endurance.

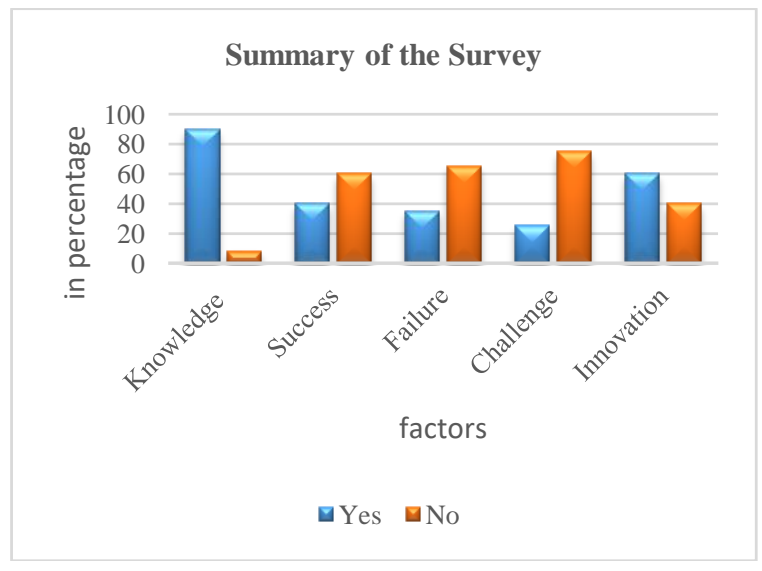

Documentation of the work was carried out and showcased using charts and the assessment is done based on their presentation which was evaluated using specific rubrics. This assessment was a part of the formative assessment of the curriculum.

The following are the reflections of their work carried out, documentation and presentation:

1. Most of the Entrepreneurs had many failure stories before their success in their business.

2. It is a matter of incredible hard work, patience, perseverance, passion, and dedication to achieve success after failing in a career.

3. Failure taught the Entrepreneurs to learn new skills, get new experiences, and begin a different chapter in life.
4. Successful entrepreneurs had followed healthy and balanced lifestyles, which creates positive energy and improves their health.

5. Failure reasons were evaluated and tried to improve towards success.

6. Time management is very critical to balance productivity without compromising work-life.

7. The goal, dedication, efforts, time-bound plans are required for the success of the projects.

The entrepreneurial lessons which are listed above cannot be taught in a mere classroom teaching using chalk and talk or PowerPoint presentations. The students who were hesitant to meet others and with a lack of communication skills were accompanied by the students who were slightly better than them in terms of self-motivation. This gave them the chance to learn from the performance of their peers and also inculcate those qualities in them. The heterogeneous team had students with different learning styles. With the prior knowledge of their learning style, this was possible.

\section{Results and Discussions}

Improving social skills and entrepreneurial skills from experiential learning was the main objective of this research. At the same time, the corporate social responsibilities of business and entrepreneurship lessons ensured that students develop the concern towards society and the needy. It is very enlightening to declare that the experience of the entrepreneurs taught the lessons to the students far better than an engineering educator in a more effective way. Observation from their working and presentation also observed that their critical thinking is improved significantly while performing the given project.

Students have started getting a more realistic view of the entrepreneurs and their journey. Reaching and interacting with Entrepreneurs changed their perspective towards business. Also, it enabled students to take the leadership, recognize and resolve problems, function in teams, balance risks, and effectively communicate with others in very different domains.

Few outcomes of the first activity conducted have been summarized here.

Table 1. Students findings from PBL

\begin{tabular}{|l|l|l|}
\hline Team & $\begin{array}{l}\text { Visited Company } \\
\text { /Enterprise }\end{array}$ & Learnings \\
\hline 1 & $\begin{array}{l}\text { Solic- online marketing } \\
\text { company }\end{array}$ & $\begin{array}{l}\text { How the company } \\
\text { started, Prerequisites to } \\
\text { start a company, } \\
\text { motivation to start a } \\
\text { company Networking } \\
\text { with people and its } \\
\text { advantages }\end{array}$ \\
\hline 2 & Textile industry & $\begin{array}{l}\text { The different type's } \\
\text { fabrics and yarns, } \\
\text { Marketing strategies, } \\
\text { product and pricing } \\
\text { strategy, }\end{array}$ \\
\hline
\end{tabular}




\begin{tabular}{|c|c|c|}
\hline & & $\begin{array}{l}\text { advertisements, Set sale } \\
\text { and profit goals, } \\
\text { Customer Service }\end{array}$ \\
\hline 3 & $\begin{array}{l}\text { D \& D Smart Labs - } \\
\text { electronic } \\
\text { manufacturing and } \\
\text { services }\end{array}$ & $\begin{array}{l}\text { Services and strategies } \\
\text { of the company, } \\
\text { Intellectual uplift from } \\
\text { the founders for the } \\
\text { start-ups }\end{array}$ \\
\hline 4 & Food Industry & $\begin{array}{l}\text { The roles and } \\
\text { responsibility of } \\
\text { managers, importance } \\
\text { of customer services, } \\
\text { ways of Sustainability }\end{array}$ \\
\hline 5 & NGO & $\begin{array}{l}\text { Act of laws and } \\
\text { sections to start an } \\
\text { NGO, variety of service } \\
\text { and humanitarian } \\
\text { functions }\end{array}$ \\
\hline 6 & Event Management & $\begin{array}{l}\text { Teamwork, } \\
\text { coordination, the } \\
\text { expertise required to } \\
\text { create innovative } \\
\text { designs with the latest } \\
\text { trends }\end{array}$ \\
\hline 7 & Automobile Industry & $\begin{array}{l}\text { Importance of step by } \\
\text { step growth, team spirit, } \\
\text { Effect of } \\
\text { demonetization over the } \\
\text { business, never give up, } \\
\text { expansion of the } \\
\text { business }\end{array}$ \\
\hline 8 & Pharmaceutical Industry & $\begin{array}{l}\text { Need of license, } \\
\text { educational } \\
\text { requirements, } \\
\text { guidelines to be } \\
\text { followed to run this } \\
\text { business, collaboration } \\
\text { with other medical } \\
\text { organizations, the risk } \\
\text { involved, Choosing a } \\
\text { right location for the } \\
\text { business, competency } \\
\text { required and } \\
\text { competition involved, } \\
\text { the process of hiring the } \\
\text { employees, customer } \\
\text { service, first get } \\
\text { experience, Marketing } \\
\text { strategy }\end{array}$ \\
\hline 9 & Cosmetic Industry & 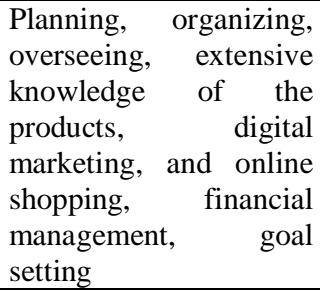 \\
\hline 10 & Family business & $\begin{array}{l}\text { Pros and cons of the } \\
\text { family business, } \\
\text { honesty, never lose } \\
\text { patience, be customer- } \\
\text { friendly, and never lose } \\
\text { sight of goals. Always } \\
\text { work hard, faithful to } \\
\text { the customers, and } \\
\text { sensitive to their needs. }\end{array}$ \\
\hline
\end{tabular}

By this activity engineering students who wanted to pursue their career in management and entrepreneurship or wanted to create their venture/start-up were exposed to enough basic knowledge through inquiry-based/problembased learning. Students turned up with new business ideas by perceiving gaps and issues in how customers are being served. To some extent, they also came across the people who are already in the business and started the process of their choice. This gave them the overall insights on the importance of innovation in entrepreneurship. It is quickly acknowledged that there are noteworthy differences between the traditional teaching method and Problem Based Learning. In traditional teaching, there is a formative and summative assessment done through the exams that evaluate the knowledge acquired from classroom lectures and selflearning materials. On the contrary, during Project-based learning, there are multiple steps, including instructions by the professor, regarding the concept to be covered in the planned activities, workshops, labs, and projects, with adequately set rubrics of evaluations. In this kind of assessment process, professors must be more impartial and unprejudiced and guide their students to a better learning process and fullness of life. Besides this, PBL gauges social skills including cognitive and emotional competencies accomplished by the students - in comparison to the traditional teaching method that assesses only cognitive ones. Also, through the PBL teaching technique, students could collaborate, contribute, communicate, and utilize their critical thinking under their mentor's or professor's guidance throughout the implementation of their project. This pedagogical practise was found to be the most effective one in terms of student's involvement in learning. Students learned to go in self-learning mode.

This research has assisted the students to bring out the capabilities in them. The impact was quite appreciable and impressive. Thirty students enrolled in the NAIN (New Age Innovation Network) program from Karnataka Innovation and Technological Society, Government of Karnataka. NAIN is designed to allow students, research scholars, and alumni of the chosen colleges to identify the local problem, need and find a solution to that. Also, financial support up to 3 lakhs will be given to the team to prepare the prototype, and further support will be given to continue the work and form a start-up. The following are the details of student's business plans who have registered under NAIN. 
Table 2.Business plans

\begin{tabular}{|c|c|c|}
\hline No & Project Title & Sector \\
\hline 1 & $\begin{array}{l}\text { PLASTICS } \\
\text { UPCYCLING } \\
\text { Development Of Waste } \\
\text { Plastic Bricks - Lumber }\end{array}$ & Social Innovation \\
\hline 2 & $\begin{array}{l}\text { Design And Fabrication } \\
\text { Of Combined Wheelchair } \\
\text { And Bed }\end{array}$ & Social Innovation \\
\hline 3 & Automatic Lawn Mover & Technology Innovation \\
\hline 4 & $\begin{array}{l}\text { Remotely } \quad \text { Operated } \\
\text { Lifeguard }\end{array}$ & Technology Innovation \\
\hline 5 & $\begin{array}{l}\text { Autonomous And } \\
\text { Gesture-Controlled } \\
\text { Wheelchair }\end{array}$ & Social Innovation \\
\hline 6 & Data Centres Using Li-Fi & Technology Innovation \\
\hline 7 & $\begin{array}{l}\text { Design And Fabrication } \\
\text { Of Automated Prosthetic } \\
\text { Arm }\end{array}$ & Technology Innovation \\
\hline 8 & $\begin{array}{l}\text { Katha - Coconut Husk } \\
\text { Utensil Cleaner }\end{array}$ & Social Innovation \\
\hline 9 & $\begin{array}{l}\text { PV Solar Geyser With } \\
\text { Panel Cleaning System }\end{array}$ & Social Innovation \\
\hline 10 & $\begin{array}{ll}\text { Mobile }- & \text { Patient } \\
\text { monitoring kit } & \\
\end{array}$ & Health \\
\hline 11 & $\begin{array}{l}\text { Design And Fabrication } \\
\text { Of Portable Multi- } \\
\text { Tasking Water Recycling } \\
\text { Unit For Domestic } \\
\text { Application. }\end{array}$ & Technology Innovation \\
\hline 12 & $\begin{array}{ll}\text { Plastic } & \text { Recycling } \\
\text { Machine } & \\
\end{array}$ & Social Innovation \\
\hline 13 & $\begin{array}{l}\text { Development Of Sun } \\
\text { Dried Agro-Processing } \\
\text { Machine }\end{array}$ & Social Innovation \\
\hline 14 & Women Safety Watch & Electronics \\
\hline 15 & $\begin{array}{l}\text { D\&D Hybrid BCI (Brain } \\
\text { Controlled Interfacing) } \\
\text { Goggles }\end{array}$ & Technology Innovation \\
\hline
\end{tabular}

Finally, research has assisted in bringing out the answer to the RQs.

RQ1: The inquiry-based learning enabled the students to understand the process of entrepreneurship and the challenges involved in terms of time Management, Cash Flow Management, and delegation of responsibility among the employees who often fall short of time while accomplishing their objective by the causal interaction with the entrepreneurs.

RQ2: Through this Project, students realized the different kinds of assistance provided to promote entrepreneurship by various agencies. They documented that Entrepreneurs require robust support and a consultative system to grow their start-up ideas into valuable and profitable businesses. It generated a zeal and motivation in them to have their start-up.

RQ3: It is gathered that the strategies for the effective implementation of project Based learning on Entrepreneurial and social skills development lies in the teacher's belief and commitment. It requires choosing a convenient project and providing the appropriate inputs as the project needs. The implementation of various teaching-learning practices provided an opportunity for the students to evolve their abilities in the field of interest and potential to accept various possibilities in the venture.

\section{Conclusion}

Entrepreneurship is a life skill. It has to be an educational experience open to everyone. During the study it was observed that studying about entrepreneurship uplifts scientific, managerial, and social skills, and blossoms leadership and networking potentialities. It will help students to implement solutions to problems, think beyond current approaches, help to design insightful alternatives, embrace deliberate approaches, and create organizational procedures to investigate and implement good business ideas into reality. As a progressive result, three student teams have received funding from the NAIN -SJEC incubation center for their innovative project ideas. The future belongs to the innovators and leaders who think differently and act accordingly to reach their goals. Our education system also needs to adapt to changes accordingly. Attitudes of the students toward entrepreneurship are changing since it assembles proficiency to shape their novel ability and personality. Belief in their ability to accomplish is also fundamental to successfully implement PBL. Academic institutions can unleash entrepreneurial skills of the students through imparting experiential learning. Assessing aspirational outcomes could be considered as one of the alternative modes of assessment in this pedagogy because it kindles lifelong learning and encourages inquiry beyond the classroom.

There is a gap between what educational institutions offer and what is necessary for the project implementation in a modern, complex work environment. Therefore, there is a need to identify the main tools for the evolution of entrepreneurial skills among students. The purpose of this research is to discover the impact of project-based learning in universities globally on the development of entrepreneurial skills of students. 
To conclude, it is encouraging to note that the faculty of engineering colleges, in particular, are adopting such PBL methods to improve their delivery and inculcate selflearning among students. Teachers or professors are required to spend a considerable duration of time preparing the course material and assessment methods. The novelty in delivery is much appreciated among the student community. However, the restrictions associated with the duration of the project's realization, syllabus completion, and time frame is to be considered.

\section{References}

[1]. Lancioni, R. A. and Chandran, R. (2009) Managing knowledge in industrial markets: New dimensions and challenges, Industrial Marketing Management, 38(2), 148-151.

[2].Fayolle, A. and Gailly, B. (2008), "From craft to science: Teaching models and learning processes in entrepreneurship education" Journal of European Industrial Training, 32, 7, 569-593.

[3]. Mueller, S. and Anderson, A. R.(2014), "Understanding the entrepreneurial learning process and its impact on students' personal development: A European perspective" International Journal of Management Education. International Journal of Management Education (ISSN 1472-8117)

[4]. Van Auken, H. (2013). Influence of a culture-based entrepreneurship program on student interest in business ownership. The International Entrepreneurship and Management Journal, 9, 261-272.

[5]. Robert J. DeFillippi (2001) Introduction: ProjectBased Learning, Reflective Practices and Learning, Volume: 32 issue: 1, page(s): 5-10

[6]. Joseph S. Krajcik and Phyllis C. Blumenfeld (2006) Project-Based Learning, In the Cambridge Handbook of the Learning Sciences(2006) R. Keith Sawyer (ed). Cambridge University Press, Chapter 19

[7]. Gabriela Boldureanu, Alina MăriucaIonescu, AnaMaria Bercu, MariaVioricaBedrule-Grigorut,ă, DanielBoldureanu,(2020), Entrepreneurship Education through Successful Entrepreneurial Models in Higher Education Institutions
[8]. Vanessa Ratten, PetrusUsmanij(2020), Entrepreneurship education: Time for a change in research direction? , The International Journal of Management Education

[9]. Gladys YaaSaahOppong, Saumya Singh and FedricKujur (2020), Potential of digital technologies in academic entrepreneurship - a study, International Journal of Entrepreneurial Behavior \&Research, ISSN: $1355-2554$

[10].Xingjian Wei, Xiaolang Liu, and JianSha, (2019),

How Does Entrepreneurship Education Influence the Students' Innovation? Testing on the Multiple Mediation Model

[11]. AnisRahmawati*, NunukSuryani, Muhammad Akhyar, and Sukarmin (2020), Technology-Integrated Project-Based Learning for Pre-Service Teacher Education: A Systematic Literature Review Open Engineering Volume 10: Issue 1

[12]. Woro Sumarni1 (2013) The Strengths and Weaknesses of the Implementation of Project-Based Learning: A Review, International Journal of Science and Research (IJSR) ISSN (Online): 2319-7064

[13]. R. Wilburn Clouse, Joseph AnielloFrancis, Joseph Biernacki, (2004), A Problem-Based Learning Environment for Engineering Entrepreneurship

[14]. Kathleen Farrell, Thomas Cooney, Christina Benson, Gary Palin, Understanding the Relationship between Entrepreneurship Education, Experiential Learning and Business Ethics

[15]. DouladeliEfstratia,(2014), Experiential education through project-based learning

[16].NyaiCintang, DewiLiesnoorSetyowati, Sri SulartiDewantiHandayani, (2018) The Obstacles and Strategy of Project-Based Learning Implementation in Elementary School, Journal of Education and Learning [17]. SheebaSardarAli,(2019), Problem Based Learning: A Student-Centered Approach, Published by Canadian Center of Science and Education ISSN 1916-4742.

[18].HidayetTİFTİK, Etlik - Keçiören / Ankara,(2014), A Survey of Entrepreneurial Tendencies Candidate Young Entrepreneurs: Foundation University Sample 